\title{
'The Core of My Work Is in Being with People Who Do Not Practise Faith in Any Way': The Self-Perception of Czech Hospital Chaplains*
}

\author{
ANDREA BELÁŇOVÁ** \\ Institute of Sociology, Czech Academy of Sciences, Prague
}

\begin{abstract}
The article focuses on the understudied topic of contemporary hospital chaplaincy in the Czech Republic, its development, and the current issues this work is dealing with. Based on a study conducted among Czech hospital chaplains affiliated with the Evangelical Church of Czech Brethren, the Roman Catholic Church, the Czechoslovak Hussite Church, and the Church of Seventh Day Adventists, the article examines the experiences of Christian providers of spiritual care in the secularised environment of a hospital and sheds light on how they perceive their work and role. Two waves of interviews were conducted among thirteen hospital chaplains, male and female, and subjected to an applied thematic analysis. This produced four thematic areas that the article explores in detail: (1) the localisation of the chaplaincy within the hospital, (2) the chaplains' methods of working with patients, (3) the chaplains' relationships with other hospital personnel, and (4) the selfidentification of the hospital chaplains. The results of this research revealed that the secularised environment of the Czech Republic is a crucial factor that affects the work of chaplains in several ways, but their role in the hospital has at the same time developed in ways that are separate from their religious affiliation, as the understanding dialogue they engage in with patients forms a core part of their work.
\end{abstract}

Keywords: Czech Republic, hospital chaplains, secularised institution, chaplaincy

Sociologický časopis/Czech Sociological Review, 2022, Vol. 58, No. 3: 285-308

https://doi.org/10.13060/csr.2022.013

\section{Introduction}

This article sheds light on the chaplaincy profession that is currently developing in hospitals in the Czech Republic. The focal interest is the experience of hospital chaplains themselves. Chaplaincy has gained new attention from scholars owing

\footnotetext{
* This work was supported by the Czech Science Foundation under grant GA21-01429S 'Centenary of the Czechoslovak Hussite Church: A Historical-Sociological Synthesis'.

** Direct all correspondence to: Andrea Beláňová, Institute of Sociology, Czech Academy of Sciences, Jilská 1, 11000 Prague 1, Czech Republic, e-mail: Andrea.Belanova@soc.cas.cz.
}

(C) Sociologický ústav AV ČR, v. v. i., 2022

(C) Author, 2022 
to a documented increase in the secularisation of public institutions, which has led to a 'paradigm shift' of the role of religion in the public space [Norwood 2006: 7], leaving religious groups with less authority [De Groot 2010; Martínez-Ariño and Griera 2018]. At the same time, in recent decades, the reintroduction of spirituality into medical practice has increased the importance of religious experts in hospitals [Norwood 2006]. This trend has only continued through the current pandemic, as attention has turned to spiritual care during the health crisis [Bard 2020] and to the role of chaplains as figures who can support patients in the absence of family members [Riggs 2020].

Studies indicate that hospital chaplains are often viewed as 'jacks-of-alltrades' by their institutions [Martínez-Ariño and Griera 2018: 150; Weaver et al. 2008]. For instance, Martínez-Ariño and Griera [2018] identified in their research four major roles that Spanish chaplains serve beyond their official work tasks: providing social services to fill in gaps in welfare services, dealing with religious illiteracy and diversity, attending to problematic situations, and sometimes serving as religious innovators. Data from different countries also seem to suggest that the chaplain role is still professionalising and leaving strict denominational borders [De Groot 2018; Martínez-Ariño and Griera 2018; Norwood 2006]. This professionalising trend is also evidenced by the existence of the special Journal of Health Care Chaplaincy, indicating that chaplains themselves are also taking a more active part in the research itself [Piderman and Johnson 2009; Weaver et al. 2008].

Hospital chaplains usually view their role as primarily that of representing a human approach in the cold medical world since they are trained to be patientcentred [Piderman and Johnson 2009]. This aspect of humanity is expressed as empathy, patience, accompaniment, closeness, and participation in a patient's personal story [Harvey et al. 2008]. However, hospital patients are people of different approaches to spirituality and religion. Two distinctive subgroups deserve closer attention in this regard. First, there are patients who find themselves in a religious struggle as they have negative religious coping - for example, where they are 'feeling abandoned or punished by God' [Piderman and Johnson 2009: 14]. Second, there are patients at spiritual risk, whose 'religious needs are high, but their religious resources are low' [ibid.]. The second group appears less likely to ask for a chaplain's assistance, as their needs can be very specific. To be open and learn about a patient's spirituality is described as a new demand that the diversity and privatisation of religion has brought to chaplaincy [ibid.]. The approach to patients, issues relating to the institution and other personnel, and the self-understanding of Czech hospital chaplains are the main focus of this article.

\section{Hospital chaplaincy in the Czech Republic}

Pastoral care has been provided at Czech medical institutions since the Middle Ages. In the 1950s the communist regime stopped the clergy, members of religious orders, and pastors from being present in hospitals, and this remained the 
situation for almost 40 years. The 1989 Velvet Revolution made the slow revival of chaplaincy possible. Baštecká, Doskočil, and Janečková [2020] state that, in comparison with the situation abroad, two different tendencies affecting spiritual care in hospitals can be observed in the Czech Republic: the level of secularisation is higher in this country than elsewhere, while the experience with hospital chaplaincy is shorter than in many other countries.

The development of hospital chaplaincy in the Czech Republic after 1989 was slower in comparison with prison and army chaplaincies. The process was rather unsystematic and spontaneous [Baštecká, Doskočil and Janečková 2020]. Legally, hospital chaplaincy was only sanctioned for the first time in 2006 by an agreement between the Ministry of Health, the Czech Bishops' Conference, and the Ecumenical Council of Churches. The agreement was later widened in 2011 when the necessary qualifications for hospital chaplains were defined, from which point it was determined that chaplains had to have a theological university education, had to complete a hospital chaplaincy course, and had to obtain authorisation from the chaplain's church. In a later methodical paper from 2017, the service was characterised as non-medical, non-evangelical, and voluntary on the part of care receivers. Menke [2017: 28] mentions that the religious aspect was marginal here. More interestingly still, the paper also banned spiritual caregivers from non-registered churches and groups in hospitals. The latest version of the agreement was signed in 2019 and has led to a larger formalisation of the hospital chaplaincy in the form of a compulsory qualification course that has generated pressure especially on the older and long-serving chaplains.

To date, almost half of all Czech hospitals offer a chaplain service [Nešpor 2020]. Only a portion of the chaplains are employees of their hospitals; others are only able to be present in hospitals with the financial support of their church. Czech hospital chaplains are organised within two organisations: the Association of Hospital Chaplains (ANK; Asociace nemocničních kaplanů), established in 2011, and the Catholic Association of Hospital Chaplains (Katolická asocicace nemocničních kaplani̊), which separated from the ANK in 2012 to gather the more traditional (primarily Moravian) Catholics. The first organisation does not favour any specific church affiliation but is nonetheless an entirely Christian organisation. This is, however, compelled by a law requiring pastoral care in secular institutions be provided only by churches that have been granted special rights by the state. Czech hospital chaplains can best be characterised as diverse in terms of their church affiliation, age, and gender.

New discussions and platforms about chaplaincy in general have started to appear in recent years. Most of these have been initiatives from within the inner circles of chaplaincy, but the topic has also attracted more media attention during the COVID-19 pandemic [Doskočil and Beláňová, forthcoming]. Nešpor [2020] claims that the service has become quite well known and relatively popular. Nevertheless, very little is known still about the experience of hospital chaplains themselves and their understanding of the chaplaincy role, a fact which has fostered this research. 


\section{Research design}

The article is based on a content-driven qualitative study. The data were gathered over two periods: first between 2017 and 2018 and second during 2020 and the beginning of 2021. The main aim of the first research period was to collect experiences from hospital chaplains across the Czech Republic and to understand their views on their role and work. The second period was added to enrich the original dataset by further exploring the issues raised in the first collection period and to pursue the recommendations made by reviewers.

To begin, both professional Czech hospital chaplain associations were approached and asked for contacts. In the interview scheduling, I attempted, for purposive sampling, to incorporate a variety of research sites, including both big and small hospitals, while taking into account regional differences in religiosity, ${ }_{1}^{1}$ church affiliation, and gender. During the first period, interviews were conducted in person, whereas during the second period interviews were conducted online (Skype, Zoom, Whatsapp) because of the pandemic. All the chaplains selected for this study were asked for a semi-structured interview in an e-mail message that described the main objective of the fieldwork as identifying the role they play in hospitals.

The interviews began with questions directed at personal history and the chaplain's path to the hospital. Next, I asked about the spatial facilities provided by the hospital, the daily practice of the chaplain, and the organisation of their time in the institution. Special emphasis was put on the character of interaction with personnel and patients. The chaplains were also asked about their self-perceived role. Concluding questions were aimed at the topics of highest importance and sensitivity to the chaplains. In the second period, the interviews focused more on the topics that appeared to be the ones most frequently mentioned in the first interviews, such as relationships with the hospital institution, interactions with medical personnel, methods of working with patients, and the chaplains' relationship with their church.

In total, thirteen in-depth interviews were conducted, eight in the first period (2017-2018) and five in the second (2020-21). The interviews from the first period are referred to as $\mathrm{A}$ in the article and those from the second period as $\mathrm{B}$. The sample included eight men and five women. Five of the chaplains were affiliated with the Evangelical Church of the Czech Brethren, four with the Roman Catholic Church, three with the Czechoslovak Hussite Church, and one with the Seventh Day Adventist Church. The average length of practising hospital chaplaincy (including volunteering) was five years. One former chaplain was included in the sample.

\footnotetext{
${ }^{1}$ For example, hospitals in the more secular Bohemia and the more Catholic Moravia were chosen, along with hospitals in the largely atheist Sudetenland. These differences were suggested by the chaplains themselves.
} 
The interviews were recorded and transcribed. Detailed notes were also taken. Observations were usually not possible in the hospitals during the work shift, except for visits to hospital chapels, photography, and the gathering of relevant materials, such as leaflets and promotional materials. I was also allowed to take part in two meetings of the hospital chaplains' professional associations in 2019 and 2020. My notes from these meetings are part of the analysis and are marked in the text as E1 (Event 1) and E2 (Event 2). All the data were anonymised so that neither the hospitals nor the chaplains can be identified in the text.

The final dataset consisted of interview transcripts, text-based field notes, and the chaplains' printed promotional materials. The data were analysed according to methods usually referred to as applied thematic analysis (ATA), while the codes were derived from the data [Guest, MacQueen and Namey 2012]. This inductive method made it possible to identify key themes and to create a codebook during a re-examination of the materials. The first analysis period was guided by a desire to understand the identity of the Czech hospital chaplain. The first round of coding revealed four main areas of concern: the self-localisation of the chaplains within the institution, the chaplains' methods of working with patients, the chaplains' position among other personnel, and the self-understanding of chaplains. The second coding round focused on details within these areas so as to identify the main issues and problems chaplains had to deal with. The following sections provide insight into the findings according to the coding process.

\section{Findings}

\section{Self-socialisation in secularised hospitals}

As a researcher I tried in my questions to propose that there could be a conflict between the chaplains' role as rooted in religion and the secularised institution they work in. Nevertheless, the chaplains usually tried to overcome the suggested language of conflict and pointed to other issues that were of importance for them. In regard to what could be described as 'finding one's place within the space of the hospital', they mentioned the following issues: the rather slow legitimisation process for the chaplaincy, part-time contracts, questions concerning private space, and fruitful cooperation with chaplains of other denominations.

More than half of the interviewed chaplains reflected on their uneasy beginnings within the hospital. However, the secularised environment was only partly responsible for their sometimes uncomfortable start. What was a problem was that the chaplains entered the hospitals as an unknown entity, so to speak; personnel did not know who they were or what they do. These unsure beginnings usually demanded a great deal of improvisation both on the part of the chaplains and the employers (and, as is noted further on in the text, much of this improvisational approach has remained intact): 
I was just finishing my theological studies, and the former hospital chaplain there [in the hospital where this chaplain worked] was just going back to his region. So, I stayed in his place, and I also took over his duty as a chaplain. I somehow automatically became a chaplain. (A7)

The informants reflected that their first experiences were sometimes uncomfortable, especially if they were the first chaplains at the institution they were working at. The progress was at times slow and demanding:

To begin, this new service at the hospital faced difficulties because you would go to the hospital and say to everyone: 'chaplaincy services'. And you would still have to explain what that's all about. (A8)

It seems, however, that over the years chaplains have progressively incorporated themselves into the hospital structure. In many cases, time was needed for the institution to have experience with the service:

I succeeded in being invited onto the palliative team as a regular member. The head doctor wanted me there. But this is only a consequence of the fact that I've been at the hospital frequently and for a long time. (B5)

Importantly, most of the chaplains I spoke with did not do chaplaincy as a fulltime job. For many of them - and this seems typical of all Czech hospital chaplains across denominations and regions - it was a one- or two-day duty combined with other jobs and leading a parish. Below, I provide two examples from interviews:

I have an employment agreement, not a full contract, for three hundred hours a year. And that is just enough for me, though the hospital would probably like more. (B2)

I work Wednesdays and beyond that only if someone actually calls me to come. (B4)

Most of the chaplains who were interviewed chose part-time as the best solution to combine their daily duties. But it could also be seen as limiting given the character of chaplaincy work:

I'm there just six hours a week, which can be a problem with patients if their condition worsens extremely quickly. It's difficult then to be able to establish trust with them. (A6)

In all the interviews with chaplains an issue that was worth mentioning was their contract with the hospital. Not all chaplains are automatically paid by the hospital, but many of them are financially supported by their churches. Salary was 
also a hot topic and was seen as something that had to be communicated very carefully:

For six years I have done this service here for free, so to have a very part-time contract is a small victory for me now. When I started here at the hospital, I had to be very careful. I did not want to bother anyone about money ... I can only bring this up now. (B5)

On the other hand, part-time employment usually has one unintended advantage: it can lead to greater interdenominational cooperation among chaplains within one institution. Ecumenical cooperation was a frequent topic among the informants and, prevailingly, it was evaluated positively. For instance, in one hospital, two Catholic lay chaplains and a female Seventh Day Adventist chaplain share the provision of spiritual services. Another example is described as follows:

My mentor at that time, he worked with a Hussite chaplain. Later on, a Catholic priest joined us, and he is still with us now, and the Hussite chaplain has left. (A7)

It seems, however, that contracts and ecumenical cooperation were topics that related to the question of the area where the hospital is located. The particular region in which a hospital was located appeared repeatedly, especially in reference to the degree of the area's religiosity:

The problem is that there are no people, there's no one in this region who'd be interested in providing spiritual services full time. But the hospital would be interested in it. (B3)

The structure of the population and the expected nature of the region may also affect the way chaplains have had to change their thinking about patients and the work they do with them. For instance:

This region is specific, full of atheists. (A6)

Another aspect of the chaplains' presence in the institution was how they tried to become part of the hospital's physical environment. Their visible difference from other personnel was one issue that the chaplains discussed in the interviews. In most cases they were given an identification card with a photo and the name of their position. ID may be important in the process of becoming part of the structure:

As the coordinator of multiple chaplains, I insist on them having ID as a team member, even if the chaplain is not paid by the hospital. (B5) 
However, an ID card does not always mean that chaplains are immediately recognisable as such, which some consider a disadvantage. There was no clear agreement on this topic among the chaplains interviewed. One Protestant chaplain decided to wear a shirt with a collar, the way Catholic chaplains do. This particular chaplain was making a clear reference to the stereotypical appearance of Catholic priests, which is familiar to most of the population and makes him recognisable as a religious figure. A few Catholic chaplains (priests and nuns) opted for the same strategy, but doing so brought new complications given the stereotypes about religion among the patients and personnel:

When I come dressed like this, everyone knows what's going on, everyone recognises me. But, at the same time, many also think that I've come to share the faith. (B1)

The stereotype of 'passing on the faith' surfaced more often in cases where the chaplains preferred to wear religious clothing. Clothing was one of the stereotypes that chaplains mentioned bound them to their roles - other situations are described later in this text.

The organisation of the space within the hospital building was also significant. For example, the space in the hospital where the chaplains are able to store their personal belongings and have a rest was an important topic for the interviewees. Some were lucky enough to have their own office within the hospital:

You [to the interviewer] were admiring my office too, weren't you? Yes, all of it, including the furniture, that is all hospital property. They gave me the printer, PC, a phone. I really have no reason to complain. (A7)

Nevertheless, the following scenario appeared to be much more common:

I have a small shelf in the room for nurses, with a prayer book and a Bible and slippers in their bathroom. (B2)

Some chaplains are not able to store personal belongings in the hospital at all. They were viewed - and viewed themselves - as visitors who come and go and must ask on each occasion for a place to hang their coat. The hospital's willingness, or not, to provide chaplains with their own personal space affected their self-esteem. They mentioned this topic also in connection with the space of the hospital chapel. Some hospitals have no chapel and are not planning to have one in the near future, while others had them in the past but no longer do:

There is no chapel. It was closed two years ago, without even asking us chaplains.

The patients used to go there to smoke. It's now some kind of storage space. (B1) 
Nevertheless, other chaplains are more than satisfied with the state of affairs:

We have a chapel, a beautiful one, for ecumenical purposes. We have services there twice a week. (B5)

But this case seemed an exception. Interestingly, there are hospitals that have a room called the Space of Silence. As one chaplain noted, this name was a deliberate choice: 'The name is liberating for patients, because it is not a chapel' (notes from E1). The liberating aspect here derives from avoiding any overt reference to Christianity. Spaces of Silence are thought of as nondenominational, but many of them contain very Christian paraphernalia. The spaces I had the chance to see usually had a cross, chairs, and a bookshelf. The room could also be used for patients seeking privacy and silence, but it was rarely used for such a purpose:

We have a Space of Silence, which is mostly used only for religious services. I don't know if this means that we don't promote it enough or that people are embarrassed to come here. (A7)

The next important topic related to this thematic area was the integration of chaplains into the hospital regime. One chaplain laconically described the chaplain's self-localisation:

The chaplains are relegated to the margins of the hospital. And hospitals have their own problems too. (B3)

The question of (not) being a part of a medical team was an issue here:

No one knows exactly what you're doing, so it's not at all easy. The hospitals where they [chaplains] formed teams are better to work in. They have leadership, supervision, responsibilities - that's how it should be. But when there's only one chaplain in the hospital, or two, they burn out within a few years. (A8)

It seemed that the topic of belonging to a team was also crucial for self-understanding and for the effective organisation of the work, both with one another and with other personnel in the hospital:

There are three of us chaplains here. We communicate by phone and leave each other notes about the patients ... which works with the personnel too; they give us tips on whom to visit. (A6)

Not surprisingly, the level of cooperation and feeling of (not) being part of a team also affects how the chaplains evaluate themselves. Here are two examples of very different experiences: 
I am aware it's expected that the chaplain should be part of some bigger team. But up to now it hasn't worked that way here. In part, it may be my mistake - I'm more of a closed person, an introvert; I don't push these things. So, for me to be a part of an ethical committee or something like that ... never. (A7)

I regularly attend the team meetings. We work really well together. We are open to each other. We share a lot with each other about our work. I feel accepted, and I feel my approach is part of how they understand the work. We complement each other. (A4)

In sum, the ways in which the chaplains become incorporated into the structure of the hospital have a significant effect on their self-identification. The type of contract, personal space, or participation on a team were all experiences central to the chaplains' self-understanding. However, as they all indicated, their work primarily focused on the patients and their well-being.

\section{Methods of working with patients}

During the interview, the chaplains were asked how the patients learn about their service. They were aware that self-promotion was important given the nature of their work in the hospital. Because they could be left feeling that they are out on the margins and not really a part of the hospital team, they found themselves being proactive and introducing their roles and work to others. The strategies they used to do this could differ; some preferred to walk around and explain, while others used printed materials:

We cannot wait until someone approaches us, because very little is known about what to expect from the chaplain. (B5)

There is a contact for a chaplain on the bulletin board. Not everyone reads that, however. I also have leaflets where I describe my services, and I leave them on the table in the ward. (B2)

The chaplains also mentioned the stereotypes about their roles when they were explaining the nature of their work. A good example of how some people react to their work is provided by a leaflet produced by the Catholic Association of Hospital Chaplains, which emphasises the following:

Attention! Hospital chaplains are not engaged in any religious campaign, and they never offer patients miraculous healing. ... Chaplains are not allowed to try to persuade anybody to enter or change their religious affiliation!

As well as leaflets, the patients usually get information about chaplains upon entering the hospital when they complete their admissions form: 
The patients can learn about us from the admissions form. But I don't think the personnel read it carefully [so that they know which patients might want to see a chaplain]. (B1)

All the chaplains interviewed confirmed that the patients do not usually ask to see a chaplain. There could be two main reasons for this: the generally low level of institutionalised religiosity in the country and the population's unfamiliarity with the chaplaincy service.

The service has existed in this particular hospital for years, but the patients were by no means asking to see us. A very small percentage of them would ask to see us at their own initiative. (A3)

Under these conditions, the chaplains are mostly forced to 'walk around' the hospital and continuously introduce themselves. Although they may receive recommendations from personnel on whom to visit, the first moments with any patient can be uncomfortable on both sides, as the patients do not know the chaplains or do not usually expect their visits. Some of the chaplains interviewed felt that on first meeting a patient they had to adapt their strategies to get past the stereotypes attached to their role. The following excerpts describe two different strategies that chaplains use that relate to their clothing and how they introduce themselves:

As soon as they see me in my traditional robe I often hear, 'Am I dying?' So I choose the grey robe at least, instead of the black one. (B1)

When I arrive, I don't introduce myself as a chaplain but as the 'ears' of the hospital, ears that don't judge and know how to keep secrets. (B3)

Another important point that arose from the interviews was that the main aim of the chaplains was to have a dialogue with a patient that would resemble a casual conversation. The dialogue between a chaplain and a patient is usually considered a way of relieving the person's tension, while it is usually up to the patient to initiate the topic. The dialogue is more about letting the patient speak and listening to them:

When I arrive, I don't know what the patients expect, what they think our meeting is about. We have to get to that. So, I come in with the approach that I will listen, and, hopefully, I will learn what the person needs, and that we can relate to each other somehow. (A4)

I am always waiting for the questions from the patients, what they want to speak about. I never start speaking myself, and definitely not about Christ. (A7) 
Obviously, most of a hospital chaplain's work, as described in the interviews, consists of individual consultations that border on psychological therapy - the interactions with patients are calming and emphatic. An interesting question arises here: Who are the patients who interact with Czech hospital chaplains? Drawing from the interviews, it can be stated that some of them are believers, mostly affiliated with the Roman Catholic Church, who know what to expect, and who ask for the sacraments to be administered to them, for instance, even by a Protestant female chaplain. However, most patients who interact with chaplains are of a much different nature, as all the chaplains confirmed:

[They're] blank slates, I would say [laughter]. (A7)

$99 \%$ of them have no connection to the church. (B3)

Believers, but more often sympathisers with the church, and people who were baptised a long time ago, in childhood. (B2)

Many of the patients here claim to be non-believers. Their spirituality lies somewhere else [than mine]. I respect that and approach them accordingly. The core part of my work is in being with people who do not practise their faith in any way. (A3)

This experience affects how the chaplains approach their work. Religiosity is not usually a steady part of their interaction with patients:

The topic [of the conversations] is not God explicitly, but hope, suffering, motivation, sources of strength. (B3)

If you were to ask how often I use the Bible or pray with people ... then I'd answer 'not often'. (A7)

The experience of meeting this type of patient often leads chaplains to rethink their working methods:

I very rarely pull the Bible out of my pocket. I have only prayed with a patient a few times. I admit that my idea of the chaplaincy was different from this at the beginning. (A6)

The Czech society requires a special non-religious approach. What makes sense here is ecumenical or non-religious but humanistic spiritual care. (A2)

People are surprised they are not being beaten over the head with the Bible by me. 
The chaplains overall appeared to be trying to avoid the stereotypes attached to religion and to provide comfort to the patients at the same time. They also actively redefined their understanding of the conversations that they were having with patients. The absence of spirituality was not interpreted as lessening the benefits of the mutual encounter:

Very often it is about the closeness, the humanity, and we don't get to the religious stuff at all. ... Even talking about the weather can be spiritual in a way. I can pray with a person and then go bake and bring him the cake he likes ... both are spiritual acts. (A7)

In most cases the conversations are good, beneficial, though we don't talk about religious stuff. Often, there is someone in the room who rejects me, so I speak with someone else who is interested. And then the first one, the one who rejected me, joins us and then asks me to come back. (A3)

The idea of chaplains destroying the stereotypes about religion was one that very frequently came up. The chaplains prefer to talk and listen and sometimes consciously mute their religious identity to get closer to the patient. Moreover, most chaplains I interviewed were conscious of the specific Czech conditions for adopting this special non-religious approach, but at the same time they refused to abandon their own Christian identity. In some cases, the chaplains reported that they acted as intermediaries on religious issues. Mostly this meant supplying contacts for Catholic priests who could anoint the sick or for a representative from a different denomination than the chaplain's:

Yes, as chaplains here we serve as intermediaries for Catholic priests. And this works well. For the hospital this is understandable, it makes sense ... they themselves wouldn't know who to call. (B4)

Last but not least, the chaplains emphasised one big advantage that they have over other personnel when working with patients, which is time:

The chaplain is the person who always has time, whereas the personnel do not. (A1)

The chaplain? The person who can spare the time. (A2)

This self-definition led chaplains to think about how they are seen by the hospital's medical personnel. The following section refers to the chaplains' accounts of this relationship. 


\section{Working with the hospital personnel}

The patients are obviously the focus of the chaplains' attention. Chaplains try to approach them according to their needs and devote enough time to each one. However, everyday communication with the hospital personnel appears to be a much more complicated but inevitable issue. Some called it the 'weak side of the work' (A1). The chaplains shared their general sense of uncertainty about how to approach medical personnel. This is again related to the lack of definition as to what their role is:

Practically, you walk, you explain to the personnel that you are here, and they suggest this lady or that one ... Cooperating with the personnel is a number one priority, it's very important. But the personnel do not know who you are until they make an experience. (A8)

Some of the chaplains in this study also experienced unkindness from the personnel and felt like an unexpected or uninvited figure in the hospital, or even worse, they were unable to have an effective impact on the situation:

I got into a conflict with the personnel at the very beginning. One group took a 'beware of the chaplain' approach to me, which interfered with relationships with those individuals who would otherwise have been interested in talking with me. (B2)

Nevertheless, the chaplains also agreed that the relationships are very individual and depend on each individual employee and their attitude:

I feel accepted. For example, when a doctor comes to visit a patient, they give me time to finish my conversation - only a few nurses are not very nice to me. (B1)

There are several teams. I have great relationships with one, with two it's okay, and one doesn't accept me - they don't know what the chaplain is here for. (B3)

The chaplains suggested that one of the reasons for the personnel's sometimes rude attitude could have to do with the country's communist history. In many cases, the same personnel were kept on in hospitals after the regime change, and these 'old structures', as the chaplains called them, were suspicious of the chaplains' work. This mainly means that, as the chaplains put it, some personnel are not able to leave behind a militantly atheistic way of thinking:

The problem is a just the totalitarian way of thinking of the older personnel... They don't get what I am doing here, especially when I am praying with someone - They think I'm crazy. (B2) 
From time to time, you pick up a bit of a negative reaction to you, kind of like the service we provide is completely pointless ... If no God exists, a chaplain can't be of any help to a person. (A7)

As a consequence, some chaplains develop strategies to deal with the prejudice. One particular chaplain focused on his behaviour towards the personnel:

At first, I was just walking around and smiling all the time. Now the personnel approach me themselves. They asked me to take part in a conference. They are mostly friendly to me. (B5)

Another chose a more institution-focused strategy:

I have forced myself into the senior doctors meeting, two or three times, and presented the chaplaincy service to them. And I tried to explain to the doctors and the head nurses what it's about. I guess that helped too. (A7)

One interesting finding, however, is that in situations where the chaplains felt that they were truly accepted, that they were part of a team, usually a palliative team, they generally evaluated their situation and their relationships better. The closeness of the chaplain to the issue of death and their expected expertise on this matter were topics that surfaced repeatedly in the interviews. Belonging to the palliative or after-care teams was felt to be the most intuitive choice for a chaplain from the personnel side as well:

We as chaplains were asked to join the palliative department. This somehow came about on its own. (B4)

In one case palliative care was used as a reason in the debate around whether (or not) to have a chaplain in the hospital:

The head doctor pushed the possibility of having spiritual care here. Palliative care was the argument given. (B2)

Last but not least, as part of the definition of the chaplains' work they sometimes found that they were also asked to provide the medical personnel as well as the patients with spiritual counsel. The chaplains who were asked this saw it as a complicated task:

It's only happened to me two or three times that personnel asked to speak privately with me themselves ... but it's tough to find the time and space to approach them... when I manage to do so, however, they are surprised that they can speak normally with me, and I won't preach to them. (B1) 
I've only twice received a direct request to have a conversation from the personnel.

Mostly these are chats in the corridor. (A6)

Speaking in the corridors for a few minutes was found to be a typical way in which the chaplains tried to approach personnel:

It is only possible to communicate speak briefly together. I have to find room for this myself, and then I have only a few minutes to talk. (B4)

Communication with personnel, however, is more typically evaluated as functioning well. The chaplains feel they are called to attend to the cases where they're needed and that the personnel are aware of them. This 'friendliness' is at present as far as interactions between chaplains and personnel extend, as personnel only rarely and sporadically ask them for spiritual counsel, while pastoral care for personnel is rare and occasional.

To conclude this section, it is worth mentioning future directions, as some chaplains suggested that educating personnel as to the spiritual needs of patients would help with cooperation:

I really appreciate what they do. They're with the patients, all the time, in an intimate way. They must be supported. But they also have to educate themselves about the mind and the soul of the patient. (B2)

What the practical solution is to attain this 'dream', as one chaplain called it, is a difficult question. Some ideas include incorporating spiritual themes into educational seminars for the medical personnel or making the chaplains important agents in meetings with new employees. The chaplains could also be given a chance to organise a programme for the personnel. All of this could help make their roles clearer.

\section{Self-understanding}

How chaplains understand their own roles can be divided into positive claims (what I provide) and negative claims (what I'm not sure I want to be). It also includes strategies on how they can fulfil their role in the given environment and the relationships beyond the hospital (with their own church and professional organisations).

A positive self-understanding among chaplains was observed in the interviews when they described chaplains as representatives of humanity in the 'cold and mechanical world' of medicine: 
It's about empathy, companionship, offering a relationship. Medical discourse makes the patient an object, but the chaplains should provide them with understanding. (A2)

Conversely, a rather negative self-understanding was observed in the interviews in relation to the lack of a clear definition as to who a chaplain is and what he or she should do. This can have uncomfortable consequences:

A chaplain is something like a highly absorbent rag that sucks out all the inconsistencies of the system. (A1)

However, the lack of definition has a bright side, too, as many of the interviewed chaplains mentioned that they feel a significant amount of freedom during their workdays:

The main advantage of this work is that I have enough time to do what is important, and I am not constrained by any regulations. (B1)

I had a chance to write down the content of what my work consists of. That was great. At the hospital, they said to me: 'You know, we don't know about this. You'll have to explain it yourself.' [laughter] Sometimes, it even feels odd that no one oversees me, and I don't have to report anything to anyone. (A7)

Generally, though, the chaplains' working conditions and positions improved rapidly. Often there was a great deal of improvisation regarding which hospitals they visited and what they had to do. In this case, the freedom referred to above means that many of the chaplains are working rather intuitively and learning from experience as they go along:

The boundaries of being a chaplain are always shifting. But, more and more, it is clear to me what kind of dialogue is useful for patients and what isn't, as well as which patients are in need of support. (A6)

An attitude repeatedly observed among the interviewed chaplains was a sense of respect towards the hospital setting and, hence, a certain carefulness in how they spoke. The chaplains are grateful for the opportunity they have. They are aware of their marginal position in the hospital and are very careful not to break the fragile trust:

I understand my role as setting the path for future chaplains. I am happy where I am, and I am not trying to expand into other wards. (B2) 
The identity work of chaplains also encompassed the need to combine different roles in their lives. Most hospital chaplains in the Czech Republic do not work in the hospital full time but combine that role with leading a parish, for example. For many chaplains, this double duty can be a source of stress and tension:

A big issue for me is how to perform my dual role as a parson and a chaplain. That's a topic for me to deal with in the future as well. (A5)

Chaplaincy is a demanding job. It requires full engagement. I can't imagine doing it with just half the energy. If you have your own parish, you can't be the only chaplain at the hospital at the same time. (A8)

In relation to the topic of parishes, some of the chaplains interviewed mentioned the issue of the attitude of their church. Some noted that their church did not support the service their work as a chaplain as much as it could. Chaplaincy was viewed by church members as a partly forgotten service, sometimes perceived as ancillary in comparison to their parish work. The chaplains mentioned an occasional need to explain to their parish members and church officials what they really do at the hospital (notes from E2), or they noted a lack of understanding church members and the possibility of being able to share things with others:

For many people in my church, chaplaincy is a marginal issue - something like half volunteering. (A1)

The church is in many ways outdated. Its old structures have a hard time absorbing modern concepts like chaplaincy. (A4)

Some chaplains seek support in chaplain associations instead. Some claim that support from the association is much more important for them than support from the church (notes from E2):

I don't feel supported by the church. It seems like the bishop sees this work as clashing with my work for the parish. I only get support from our association. (B2)

Other chaplains would continue their work even if they did not have the official recommendation for this work from their church, as some hospitals do not care whether the chaplain has this authorisation from the church or not (notes from E2). But others were content with the way things were. Again, the chaplains' views on this topic greatly depended on the church and the individuals in it:

The church? It's okay. Our bishop understands these issues. He is open and supportive. (B5) 
A few of the chaplains also shared their worries that chaplaincy work is quite unpopular among theology students. As a result, it could in the future be difficult to find young people interested in continuing to provide this service in hospitals:

Regarding chaplaincies, we in the churches should speak more about educating new, young chaplains, providing them with internships and such. (A2)

Finally, I would like to briefly reflect on the question of the chaplains' particular distinctiveness. The chaplain's personality is what is regarded as making them unique, more so than their affiliation:

The chaplain's personality is key. The chaplain just has to be a non-confrontational person, a communicative person. (A1)

It's about the chaplain as a person. Problems may arise, but still, it's about the skills of the chaplain. (B5)

I will conclude this section with the chaplains' thoughts about their special place at the hospital, something that I called their 'distinctiveness' above. The chaplains' concluding remarks in the interviews usually pointed to their 'churchness' located within a secularised environment:

I ask myself whether it makes sense to insist on this exclusive status. To me it makes sense to be part of a team going forward. (A2)

A chaplain cannot be seen as partisan. The hospital agrees with their presence. This is an important fact. (A5)

To me, a chaplain is a machine that ploughs through prejudices. (A1)

Indeed, some of the chaplains saw themselves as warriors combating stereotypes about the church and religion. This seemed to be of added importance in the largely secularised Czech Republic.

\section{Discussion and conclusion}

In the analysis of the Czech hospital chaplains' accounts, there emerged four important thematic areas, which were described and quoted above. Within these areas the following topics appeared to be especially significant for the chaplains.

First, there are several different layers to their self-localisation within hospitals. Questions about part-time contracts are issues that were felt to require 
further discussion with both hospitals and churches, in addition to gaining new candidates for the occupation. On the other hand, the ecumenical work, largely the result of the fact that many hospitals have chaplains on part-time contracts, is vital, works well, and is unique from an international perspective [cf., e.g., Martínez-Ariño and Griera 2018]. Nevertheless, the chaplains who were interviewed all felt that they figure on the margins of the hospital. Yet, as Norwood [2006: 26] notes using the example of American hospitals, being on the margins does not mean being ignored, it means being in a position where you are 'alive and well'. In line with this claim, the Czech hospital chaplains in this sample seemed to be content, proactive, and finding their path with patience through the system.

Second, Czech hospital chaplains are met with very different reactions about what their role is when they meet patients. They can be rejected as strangers or 'bearers of foreign ideology' (a term used by Baštecká, Doskočil and Janečková [2020]), but, at the same time, their ability to talk, listen, and always have time is appreciated by the patients. However, in regard to working with patients, an especially interesting topic in the Czech context is exactly 'who' are the patients that chaplains work with. If I were to define the typical patients Czech hospital chaplains meet with, I would borrow the term 'believer-in-something' (the Czech term for this is něcista, a person who believes that something exists; Halík [2006]), without a clear religious vision but with some undefined spiritual needs. This could be close to what Weaver et al. [2008: 14-15] call 'patients at risk': people who have high spiritual needs, weak religious anchoring, and do not adhere to any one faith. The chaplains also appear here as religious intermediaries and spiritual experts, something that research from abroad had also noted [MartínezAriño and Griera 2018].

Third, with respect to how chaplains relate to other personnel, some of them experienced an uneasiness at work related to negative attitudes toward them as religious figures. This is largely the result of the country's communist history and the atheistic views of most hospital personnel. However, they agreed that these problems have greatly diminished over the decades. It seems that the secular personnel simply needed to get used to the presence of religion within the institution [Nešpor 2020].

The chaplains agreed that hospital personnel may see them as experts on unpopular topics, be it religion or, more often, the personal problems of patients, and death. It is a common experience for hospital chaplains to be approached as experts on this 'dirty work' [Martínez-Ariño and Griera 2018: 151] or on existential issues in general [De Groot 2010]. The most important intermediaries for chaplains appear to be nurses, who, at the same time, may be very unsure of what to expect from chaplains. A long-term plan to solve this problem could be to educate personnel more extensively about the spiritual needs of patients and provide personnel with targeted support [Baštecká, Doskočil and Janečková 2020]. Providing personnel with spiritual counsel was a more complicated and still open issue that the chaplains treated with care. Finding a way of integrating what they 
do with the work and routines of the personnel seems to be a universal problem among hospital chaplains [Norwood 2006]. In the Czech Republic, however, this may be further complicated by the areligious attitudes of the population.

Fourth, the last section of this article, reviewing how chaplains understand themselves, also provided some interesting insights. Chaplains understand their role primarily as introducing a human element into the cold world of medicine. The medicinal system is perceived as mechanical in contrast to the holistic world of religion [Norwood 2006]. This point, however, has complications. A chaplain who provides 'human, psychological, emotional and supportive means towards the sick, their families, other close people, visits and the personnel' [Menke 2017: 40] can be overburdened with tasks and suffer from the unsure definition of their work. Furthermore, the metaphor of a 'highly absorbent rag' that one chaplain used seems to accurately summarise the experiences of others. The chaplains in the Czech hospitals felt that they were approached in cases where other personnel did not have the skills or the time to deal with them themselves. This finding is consistent with the argument that contemporary chaplains are often 'filling the gaps' [Martínez-Ariño and Griera 2018].

Another interesting finding shows that chaplains somewhat play down their religious affiliation during their work. This seems similar to the approach taken by the Australian government's school chaplains, who claimed not to be religious in a traditional sense, and instead referred to themselves as followers of Jesus in a conscious reaction to the negative stereotypes associated with religious institutions [Isaacs and Mergler 2018]. For De Groot [2010], spiritual care in hospitals is a case where religious beliefs and practices move beyond the original religious sphere and are only partly determined by any one religion. As a consequence, the identities of chaplains may start to melt [De Groot 2018]. Norwood [2006: 20] recognises the increasingly nuanced practice of contemporary chaplains in religious and scientific discourse as leading to an 'ambivalent chaplain' who is in a constant process of negotiation, where chaplains are expected to 'facilitate' and 'initiate' spiritual care and religious rituals. Using Norwood's [2006] terms of facilitating and initiating, the Czech chaplains in this sample are more like facilitators of care and connection than the initiators of religious rituals and spiritual healing. De Groot [2010: 27] describes this process as getting 'close to, but [remaining] distinct from the psychological profession'. The downplaying of the topic of religion by chaplains could also be interpreted as a tendency to professionalise the chaplaincy. Czech chaplains and volunteers gather in professional associations outside church structures based on their profession but not on the religious affiliation.

The potential for the future development of the Czech hospital chaplaincy outside church structures can also be identified in the abovementioned 'patients at risk', who have high spiritual needs but little religious background [Weaver et al. 2008], which is exactly how an increasing portion of the Czech population can be characterised. As sociologists, we are facing what seems to be a uniquely 
Czech combination of religious apathy and atheistic views [Vido, Václavík and Paleček 2016]. However, more than strictly atheistic, the available data indicate that most Czechs are religiously indifferent and 'passively agnostic' [Vogel 2017: 453]. As scholars suggest, the Czech Republic is typical of a high level of individualised and privatised spirituality in combination with a certain 'religious illiteracy' [Václavík, Hamplová and Nešpor 2018: 101]. In an international comparison, the Czech Republic is stereotypically portrayed as one of the most secularised countries in Europe, if not in the world [Lužný and Navrátilová 2001]. A long-term distrust of religious institutions can be observed in the population [Nešpor 2010] and a negative view is taken of most attempts by churches to influence public affairs [Václavík, Hamplová and Nešpor 2018].

All these factors have a strong effect on Czech hospital chaplaincy. For example, as stated above, the strategy of not making a display of the church they belong to makes it easier to find a way to interact with patients - something that seems very helpful within the Czech environment. Menke [2017: 41] claims that Czech hospital chaplains can only succeed if they come across as ecumenically open and serving, as this can make them a 'reliable witness' to the faith of their churches and religious organisations. It seems probable that chaplains could potentially become popular figures in their churches. From the interviews it was possible to observe that the chaplains' careful work with patients helped them to overcome some deep-rooted stereotypes about religious institutions. Thus, together with the widely accepted and valued charitable and helpful role that European churches play [Manuel and Glatzer 2019], the chaplaincy has the potential to reach a wider population.

In this regard, the Czech Republic can be considered an example of a nation with a very advanced secularisation process, but the level of subjective religiousness is relatively high [Stark 1999]. This presents an essential challenge for hospital chaplains and their self-promotion. Future research on these developments would be useful, especially if it were based on long-term and in-field observations. The biggest limitation on the findings of this study has been the dramatically changing situation with COVID-19. These new experiences for chaplains, hospital personnel, and patients may affect the future development of chaplaincy as well.

ANDREA BeláŇová earned her doctorate in religious studies at the Faculty of Arts, Masaryk University. In 2012-2013, she spent one year as a Fulbright visiting researcher at the University of Nevada in Reno. Since 2018 she has been employed as a post-doc at the Institute of Sociology of the Czech Academy of Sciences and a lecturer at the Faculty of Education, Charles University. While participating in various research projects on current Czech religiosity, she focuses on the intersection of religious and secular spheres, most notably chaplaincy and the role of religiosity in relation to incarceration, re-entry, social work, and gender. 


\section{References}

Bard, T. R. 2020. 'COVID-19 and a New Normal?' Journal of Pastoral Care E Counseling 4 (2): 81-81, https: / / doi.org/10.1177/1542305020926831.

Baštecká, B., O. Doskočil and H. Janečková. 2020. 'Nemocniční kaplan-ka: Kdo to je, co dělá a s čím může pomoci.' (Hospital chaplains: who they are, what they do, and what they can help with) Sociální práce 3: unpaged.

De Groot, K. 2010. 'The Institutional Dynamics of Spiritual Care.' Revista de Estudos da Religião 10 (1): 21-28.

De Groot, K. 2018. The Liquidation of the Church. Oxon, New York: Routledge, https://doi.org/10.4324/9781315592527.

Doskočil, O. and A. Beláňová. 'Nemocniční kaplani během pandemie COVID-19.' (Hospital chaplains during the COVID-19 pandemic) Caritas et Veritas, forthcoming.

Guest, G., K. M. MacQueen and E. E. Namey. 2012. Applied Thematic Analysis. Los Angeles, CA: Sage, https://doi.org/10.4135/9781483384436.

Halík, T. 2006. 'Otázky a pochybnosti.' (Questions and doubts.) Pp. 47-54 in Český atheismus: prŕčiny, klady, zápory, edited by Spolek evangelických kazatelů. Benešov: Eman.

Harvey, K., B. Brown, P. Crawford and S. Candlin. 2008. “"Elicitation Hooks”: A Discourse Analysis of Chaplain-Patient Interaction in Pastoral and Spiritual Care.' The Journal of Pastoral Care E Counselling 62 (1-2): 48-61, https://doi.org/10.1177/154230500806200106.

Isaacs, A. K. and A. Mergler. 2018. 'Exploring the Values of Chaplains in Government Primary Schools.' British Journal of Religious Education 40 (2): 218-231, https://doi.org/10.1080/01416200.2017.1324945.

Lužný, D. and J. Navrátilová. 2001. 'Religion and Secularisation in the Czech Republic.' Czech Sociological Review 9 (1): 85-98, https://doi.org/10.13060/00380288.2001.37.11.13.

Manuel, P. C. and M. Glatzer. 2019. “'Use Words Only If Necessary”: The Strategic Silence of Organized Religion in Contemporary Europe.' Pp. 1-18 in Faith-Based Organizations and Social Welfare: Associational Life and Religion in Contemporary Western Europe, edited by M. P. Christopher and M. Glatzer. Cham: Palgrave Studies in Religion, Politics, and Policy, https://doi.org/10.1007/978-3-319-77297-4_1.

Martínez-Ariño, J. and M. Griera. 2018. 'Catholic Chaplains in Public Institutions: Contextual Opportunities and Institutional Inertia in Spanish Hospitals and Prisons.' Journal of Religion in Europe 11 (2-3): 138-160, https://doi.org/10.1163/18748929-01102004.

Menke, M. 2017. 'Nadkonfesní rozměr služby nemocničních kaplanů v ČR.' (The dimension beyond faith in the service provided by hospital chaplains in the Czech Republic) Pp. 27-45 in Církev a stát. Sborník z konference, edited by J. Benák. Brno: Právnická fakulta, Masarykova univerzita.

Nešpor, Z. R. 2010. Př́liš slábi ve víre: Česká ne/religiozita v evropském kontextu. (Too weak in faith: Czech non/religiosity in the European context) Prague: Kalich.

Nešpor, Z. R. 2020. Náboženství Dioskúrü. Česká a slovenská religiozita po rozpadu společného státu. (Dioscuri Religion. Czech and Slovak religiosity since the dissolution of the common state) Prague: Karolinum.

Norwood, F. 2006. 'The Ambivalent Chaplain: Negotiating Structural and Ideological Difference on the Margins of Modern-Day Hospital Medicine.' Medical Anthropology 25 (1): 1-29, https: / / doi.org/10.1080/01459740500488502.

Piderman, K. M. and M. E. Johnson. 2009. 'Hospital Chaplains' Involvement in a Randomized Controlled Multidisciplinary Trial: Implications for Spiritual Care and Research.' Journal of Pastoral Care E Counselling 63 (3-4): 1-6, https://doi.org/10.1177/154230500906300308. 
Riggs, A. K. 2020. ‘The COVID-19 Context Calls for a Broader Range of Healthcare Chaplaincy Models: An Exploratory Translational Study Utilizing Evolutionary Psychology and Social Neuroscience Loneliness Research.' Journal of Pastoral Care $\mathcal{E}$ Counseling 74 (4): 258-264, https://doi.org/10.1177/1542305020962417.

Stark, R. 1999. 'Secularization, R.I.P.' Sociology of Religion 60 (3): 249-273, https://doi.org/10.2307/3711936.

Václavík, D., D. Hamplová and Z. R. Nešpor. 2018. 'Religious Situation in Contemporary Czech Society.' Central European Journal of Contemporary Religion 2 (2): 99-122, https://doi.org/10.14712/25704893.2018.6.

Vido, R., D. Václavík and A. Paleček. 2016. 'Czech Republic: The Promised Land for Atheists?' Annual Review of the Sociology of Religion 7: 201-232, https://doi.org/10.1163/9789004319301_012.

Vogel, J. 2017. 'The Decline of Churches in the Czech Republic and the Question of Social Identity.' Danubius 35: 437-454.

Weaver, A. J., K. J. Flanelly and C. Liu. 2008. 'Chaplaincy Research: Its Value, Its Quality, and Its Future.' Journal of Health Care Chaplaincy 14 (1): 3-19, https://doi.org/10.1080/08854720802053796. 